\title{
Medicina alavanca crescimento da pesquisa científica no Brasil
}

\author{
Domingo Braile*
}

$\mathrm{D}$ ados divulgados pela Capes durante a $58^{\mathrm{a}}$ Reunião Anual da Sociedade Brasileira para o Progresso da Ciência (SBPC), realizada em julho, em Florianópolis (SC), mostram que, mesmo com todas as dificuldades, a pesquisa no Brasil se solidifica a cada ano.

Apesar do crescimento da economia brasileira ter sido de apenas $2,4 \%$ no ano de 2005 , a Pesquisa Científica cresceu $19 \%$ no mesmo período, passando de 13.313 para 15.777 artigos publicados! Apenas dois países tiveram um crescimento maior, a China com 29\% e a Índia com 21\%. Isto ocorreu mesmo sem aumento do financiamento para esta importante atividade no país. Deduz-se que a produtividade dos nossos pesquisadores foi mais eficaz, permitindo que o Brasil subisse mais um degrau no concerto das nações. A nossa situação ainda não é confortável: estamos na $17^{\mathrm{a}}$ posição no ranking mundial, mas é estimulante saber que estamos avançando neste importante marcador da viabilidade de um país. A produção de artigos científicos em Revistas Indexadas cresceu 50\% nos últimos cinco anos, o que significa que em três anos deveremos ocupar o $15^{\circ}$ lugar, ultrapassando dois importantes competidores, a Suíça e a Suécia.

E a grande notícia, para nós médicos, é que a área que mais se destacou no último ano foi a Médica, responsável por $20 \%$ das publicações, vencendo a disputa com a Física, que ficou com apenas $15 \%$ dos artigos, perdendo a hegemonia que durava havia muitos anos. Para a Capes, o avanço na produção de artigos médicos deveu-se principalmente ao rigor adotado na avaliação dos cursos de pós-graduação da área. Independentemente dos fatores que levaram a esta ascensão, a "conquista" do primeiro lugar mostra a força da Medicina e que o esforço dos colegas de todas as especialidades no sentido de "colocar no papel" as conquistas e avanços médicos está gerando importantes frutos.

Reflexo deste aumento de interesse pela pesquisa no Brasil, é o rápido crescimento dos acessos à Scielo. Segundo informações da entidade, a cada mês são realizados por meio da Internet 6 milhões de consultas a artigos de revistas científicas brasileiras da sua base de dados. A multiplicação dos acessos se dá num ritmo veloz - há três anos, contavam-se não mais do que 200 mil downloads de artigos por mês. A Scielo vem tendo papel decisivo na disseminação da ciência em nosso país e a Revista Brasileira de Cirurgia Cardiovascular/ Brazilian Journal of Cardiovascular Surgery (RBCCV/ BJCVS) orgulha-se de estar entre as mais de 150 publicações indexadas por esta importante biblioteca eletrônica.

Dentro deste contexto, continuamos a insistir com a indexação da nossa revista no Medline para ampliar a sua abrangência. O Dr. David Tirone está atuando junto à direção do Med Pub e do Index Medicus. Ele escreveu uma carta "endossando" a RBCCV/BJCVS e vai continuar em contato com os diretores, acompanhando o andamento do processo. Como sempre, estamos otimistas e esperamos poder dar em breve a notícia da indexação da revista.

Visando estar em consonância com os desejos dos nossos leitores e tendo consciência das exigências cada vez maiores - e necessárias! - dos cirurgiões cardiovasculares investirem parte do seu tempo em pesquisa e mesmo com o interesse cada vez maior despertado pela Medicina Baseada em Evidências, a RBCCV/BJCVS oferece desde o mês de agosto um novo serviço aos associados da SBCCV e residentes: estamos disponibilizando artigos completos ("full text") de alguns dos mais importantes periódicos internacionais na área da Cirurgia Cardiovascular e Torácica: "Annals of Thoracic Surgery”, "European Journal of Cardio-thoracic Surgery”, "Journal of Thoracic and Cardiothoracic Surgery", "Interactive Cardiovascular and Thoracic Surgery" e "Circulation".

Caso haja interesse por um determinado artigo, procure no sumário de uma das revistas acima e nos informe o ano, volume, título e páginas do artigo, faça a requisição por e-mail para brandau@braile.com.br ou brandau@sbccv.org.br. Os artigos serão enviados em até dois dias úteis exclusivamente por e-mail no formato 
PDF. Consulte-nos também sobre a possibilidade do envio de artigos de outras revistas. Gostaria de lembrar que a pesquisa e a "captura" é feita na Internet e a maioria das publicações só disponibiliza as edições a partir da década de 90 . Assim, nem sempre será possível obter artigos mais antigos.

Nas páginas 328 e 334 estamos publicando dois trabalhos antagônicos sobre a reutilização de materiais. Sentimo-nos na obrigação de publicá-los para que os leitores possam fazer suas apreciações e contribuir com sugestões que serão muito bem aceitas. Leia, também, Editorial sobre o tema na página III.

O site da revista continua sendo um sucesso e no início de setembro contava com mais de 300 cadastrados, entre autores e revisores. Lembro aos interessados em publicar trabalhos que a submissão é feita exclusivamente pelo endereço eletrônico (www.rbccv.org.br). Desde a implantação, ano passado, tivemos uma ampliação considerável no número de submissões, inclusive do Exterior, e também no tempo de tramitação dos artigos, agilizando a produção da revista, mas ainda podemos melhorar! Solicitamos aos autores e revisores que chequem periodicamente seus e-mails para verificar os avisos com pedido de revisão ou de devolução do manuscrito para as devidas correções.

Informo aos colegas que, mais uma vez, a RBCCV/ BJCVS encaminhou ao CNPq o pedido para auxílio editorial. Embora a verba tenha diminuído nos últimos anos e demore alguns meses a ser aprovada e liberada, ainda é de extrema importância para pagar as despesas com editoração, impressão e postagem, cujos custos têm se elevado, mesmo com a estabilidade econômica e cambial. Os anúncios que temos, embora de empresas e entidades de reconhecida relevância, ainda são poucos.

Por isso, mais uma vez pedimos aos que têm contato com empresas que atuam no ramo da Cirurgia Cardiovascular e Cardiologia e outras, que conversem com os responsáveis e mostrem a revista que, lembramos, é o veículo de comunicação dos Cirurgiões Cardiovasculares, sempre interessados em aparelhos e materiais que agreguem qualidade ao seu trabalho. Eu, o Editor Executivo Ricardo Brandau e a assistente Editorial Rosangela Monteiro, teremos prazer em fornecer as informações que os anunciantes em potencial julguem necessárias para que venham estampar suas marcas em nossas páginas.

Recebam meu caloroso abraço,

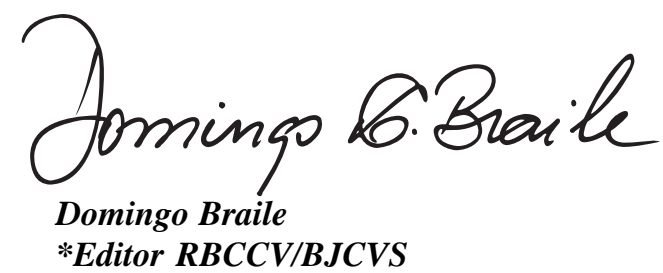

